\title{
Aligning pedagogy with physical learning spaces
}

Citation for published version (APA):

van Merrienboer, J. J. G., McKenney, S., Cullinan, D., \& Heuer, J. (2017). Aligning pedagogy with physical learning spaces. European Journal of Education, 52(3), 253-267. https://doi.org/10.1111/ejed.12225

Document status and date:

Published: 01/09/2017

DOI:

10.1111/ejed.12225

Document Version:

Publisher's PDF, also known as Version of record

Document license:

Taverne

\section{Please check the document version of this publication:}

- A submitted manuscript is the version of the article upon submission and before peer-review. There can be important differences between the submitted version and the official published version of record.

People interested in the research are advised to contact the author for the final version of the publication, or visit the DOI to the publisher's website.

- The final author version and the galley proof are versions of the publication after peer review.

- The final published version features the final layout of the paper including the volume, issue and page numbers.

Link to publication

\footnotetext{
General rights rights.

- You may freely distribute the URL identifying the publication in the public portal. please follow below link for the End User Agreement:

www.umlib.nl/taverne-license

Take down policy

If you believe that this document breaches copyright please contact us at:

repository@maastrichtuniversity.nl

providing details and we will investigate your claim.
}

Copyright and moral rights for the publications made accessible in the public portal are retained by the authors and/or other copyright owners and it is a condition of accessing publications that users recognise and abide by the legal requirements associated with these

- Users may download and print one copy of any publication from the public portal for the purpose of private study or research.

- You may not further distribute the material or use it for any profit-making activity or commercial gain

If the publication is distributed under the terms of Article $25 \mathrm{fa}$ of the Dutch Copyright Act, indicated by the "Taverne" license above, 


\title{
Aligning pedagogy with physical learning spaces
}

\author{
Jeroen J. G. van Merriënboer ${ }^{1}$ | Susan McKenney ${ }^{2}$ | \\ Dominic Cullinan ${ }^{3}$ | Jos Heuer ${ }^{4}$
}

\author{
${ }^{1}$ Department of Education Development \\ and Research, Maastricht University, FHML, \\ 6200 MD, Maastricht, The Netherlands \\ ${ }^{2}$ University of Twente, Enschede, 7522 NB, \\ The Netherlands \\ ${ }^{3}$ SCABAL Architects, London, EC1N 8BQ, \\ UK \\ ${ }^{4}$ Werkplaats Kindergemeenschap, \\ Bilthoven, 3723 BA, The Netherlands \\ Correspondence \\ Jeroen J. G. van Merriënboer, Department \\ of Education Development and Research, \\ Maastricht University, FHML, PO Box 616, \\ Maastricht, 6200 MD, The Netherlands. \\ Email: j.vanmerrienboer@maastrichtuniver- \\ sity.nl
}

\begin{abstract}
The quality of education suffers when pedagogies are not aligned with physical learning spaces. For example, the architecture of the triple-decker Victorian schools across England fits the information transmission model that was dominant in the industrial age, but makes it more difficult to implement student-centred pedagogies that better fit a modern knowledge society. Yet, very little is known about how to reach powerful alignment of pedagogies and physical learning spaces. This article aims to fill this gap by describing a participatory design process to help to realise physical spaces and school buildings that optimally support specific visions of learning and pedagogy. Three phases are distinguished in this design process: (1) specifying the pedagogy, (2) aligning the pedagogy with seating arrangements and physical learning spaces, and (3) realising the school building. Particular attention is given to the core tasks relating to pedagogy (phases one and two), and especially the second phase, in which school management, teachers and students on the one hand, and architects and interior designers on the other must collaborate in a participatory design process. Illustrations are given from two schools, UCL Academy in London, UK, and De Werkplaats Kindergemeenschap in Bilthoven, The Netherlands.
\end{abstract}

\section{1 | INTRODUCTION}

Schools struggle to carry out educational change within the constraints of surrounding infrastructures. Whilst much has been written about this challenge with regard to human, social and policy infrastructures, considerably less scholarship examines change in relation to physical learning spaces. Yet we know that the quality of education may suffer when pedagogies are not aligned with physical spaces. For example, the architecture of the triple-decker Victorian schools across England fits the information transmission model that was dominant in the industrial age (Lodge \& Reed, 2003) but makes it more difficult to implement student-centred pedagogies that better fit a modern knowledge society. The problem is, however, not constrained to old school buildings. In The Netherlands, there have been recent examples of brand new prestigious school buildings that were found to be totally unsuitable for teaching (Parlementaire Monitor, 2016). For decades, the evaluation of school learning environments has focused on the technical performance of 
facilities, with little attention to their pedagogical performance or effectiveness (Fisher, 2005). As a result, little is known about how to optimally align pedagogies and physical learning spaces (Watson, 2007). This article addresses this need and describes a participatory design process to help to create physical spaces and school buildings that optimally support specific visions on learning and pedagogy.

Three phases are distinguished in this participatory design process. The first uses the four-component instructional design model (4C/ID; van Merriënboer \& Kirschner, 2013) to define pedagogy as an interplay between working on learning tasks, studying supportive information, consulting procedural information, and practising routine skills. In the second phase, seating arrangements and physical learning spaces that support enactment of the specified pedagogy are developed. The third phase concerns the school building and interior furnishings.

Participatory design is important in all three phases: In the first, school management, teachers and students are lead partners in the design process (Könings, Seidel, \& van Merriënboer, 2014). In the second, equal participation between school management, teachers and students on the one hand, and architects and interior designers on the other are crucial (Muijs, 2010). In the third phase, architects and interior designers serve as the leading partners. In the next sections, Illustrations are given from two schools: UCL Academy in London and De Werkplaats Kindergemeenschap in Bilthoven, The Netherlands. With greater attention to the first two phases, which feature the participation of educators and learners, the approach described in this article can help schools to achieve educational change through the synergistic development of a new pedagogy, together with physical learning spaces. This article offers a generic approach and two examples, but no cookbook recipes for the design process. Furthermore, it is important to note that the approach described here is largely pedagogically agnostic, that is, we offer a generic approach to support the alignment of pedagogical vision and enactment which is amenable to the specific wishes of individual schools. In the discussion section, implications of this approach for educational policy are discussed.

\section{PHASE 1: SPECIFYING THE PEDAGOGY}

Although there are many modern pedagogies, such as project-based education, task-centred learning, competency-based education, team-based learning and problem-based learning, to name just a few, they all share common characteristics. Merrill (2012) summarises these in his 'first principles of instruction'. Based on a comprehensive study of modern approaches to teaching and learning, he formulates five principles that are shared by all of them: (1) task-centred learning - where education is best centred on real-world tasks, (2) activation - students learn more when they are directed to recall relevant prior knowledge, (3) demonstration - students learn more when new knowledge is demonstrated to them in the context of real-world tasks, (4) application - students learn more when they perform real-world tasks and receive appropriate guidance and feedback, and (5) integration students learn more when they are encouraged to integrate their newly acquired knowledge in personal or professional life.

A model that is fully consistent with Merrill's first principles of instruction and also allows for the systematic design of educational programmes is four-component instructional design (4C/ID; van Merriënboer, 1997). It is receiving increasing attention because it supports current trends in education: (a) a focus on the development of complex skills or professional competencies, (b) increasing emphasis on the transfer of what is learned in school to new situations, including the workplace, and (c) the development of 21st century skills that are important for lifelong learning. A basic assumption of the 4C/ID model is that modern educational programmes can always be described as an interplay between four basic components, namely (a) learning tasks, (b) supportive information, (c) procedural information, and (d) part-task practice (see Table 1). 4C/ID is a theoretical model, but the Ten Steps to Complex Learning (van Merriënboer \& Kirschner, 2013) presents a practical version: a path from an educational problem to a specified pedagogy in a way that students and practitioners (both designers and teachers) can understand and easily use. Van Merriënboer and Kester (2008) discuss the empirical validation of the model, as well as its past applications and Francom (2017) positions the model in the current field of educational design. 
TABLE 1 The four components and their main characteristics

$\begin{array}{ll}\text { Component } & \text { Characteristics } \\ \text { Learning tasks } & \text { Preferably based on real-life tasks or problems } \\ \text { - Broad variety of learning tasks is needed } \\ \text { - Gradual increase of complexity } \\ \text { - Gradual decrease of instructional support and guidance } \\ \text { - Helps students with problem solving, reasoning and decision making } \\ \text { - Helps to build mental models of the learning domain } \\ \text { - Helps to construct cognitive strategies of how to systematically approach } \\ \text { - tasks in this domain } \\ \text { - Instructional methods help students to integrate the new information with } \\ \text { - Helps they already know } \\ \text { - Helps to develop cognitive rules, specifying what to do under particular conditions } \\ \text { - Instructional methods tell students just-in-time how to perform the steps } \\ \text { of the procedure } \\ \text { - Only for procedural aspects that need to be developed into fully automated routines } \\ \text { - Provides repetitive practice } \\ \text { - Should be provided in fruitful cognitive context }\end{array}$

\section{1 | Component 1: Learning tasks}

Learning tasks are treated as the backbone of an educational programme. A learning task can be a case, project, professional task, problem, or assignment that students work on, either individually or in a team. Students can perform these tasks in a simulated task environment (in school) and/or in a real-life task environment (e.g., daily life or, for vocational and professional education, the workplace). Simulated task environments can vary from very low fidelity, for example, a 'paper-and-pencil' case ('Suppose you are a biologist and you encounter the following problem. ..'), or a role play or project in the classroom, to high fidelity, for example a high-fidelity hospital simulated bedroom to practise nursing skills in a school for vocational education. Learning tasks are preferably based on whole tasks that appeal to knowledge, skills and attitudes that are needed to perform tasks in daily life or in one's future profession. In addition, the tasks include carrying out both non-routine skills, such as problem-solving, reasoning, and decision making, and procedures which are always performed in the same way (van Merriënboer, 2013). Learning tasks drive a basic process known as inductive learning - students learn by doing and by being confronted with concrete experiences.

Effective inductive learning is only possible when three requirements are met: (1) variability of practice, (2) simpleto-complex sequencing, and (3) fading guidance. First, there must be a broad variety of learning tasks in the whole curriculum (Marton \& Pang, 2006). Only then will it be possible for students to transfer their acquired knowledge and skills to out-of-school settings. Second, students will begin working on relatively simple learning tasks and, as their expertise increases, on more and more complex tasks This is also known as the 'spiral curriculum' (Bruner, 1960). Third, students will often receive guidance. When they start working on more complex tasks, they will initially receive guidance from their teacher or instructional materials. At each level of complexity, guidance gradually fades until students are able to perform the tasks independently (Renkl \& Atkinson, 2003). Only then are they ready to progress to a next level of complexity.

\section{2 | Component 2: Supportive information}

Supportive information helps students to perform the non-routine aspects of learning tasks which include problemsolving, reasoning, and/or decision making. Teachers often call this supportive information 'the theory' and it is typically presented in study books, lectures, and online learning resources. It describes how the task domain is organised, helping students to develop 'mental models' of this domain and see how problems in the domain can be approached in 
a systematic fashion (i.e., how the actions of the task performer are organised in the domain) and develop 'cognitive strategies' to solve problems in the task domain.

Pedagogical methods for the presentation of supportive information help students to activate their prior knowledge and establish meaningful relationships between the newly-presented information (e.g., an explanation or demonstration given by the teacher) and the knowledge they already possess. Providing cognitive feedback plays an important role in this process. It stimulates students to critically compare their own mental models and cognitive strategies with those of others, including experts, teachers, and peer students.

\subsection{Component 3: Procedural information}

Procedural information helps students to perform aspects that are always carried out in the same way (e.g., doing additions or multiplications, spelling, applying a formula in physics, operating an instrument in a practical). It is also called just-in-time information because it is best provided during the performance of particular learning tasks when students need it. It typically consists in 'how-to' or 'step-by-step' instructions given to the student by a teacher, quick reference a guide or mobile app, explaining how to perform the steps of the procedure whilst doing it. The advantage of teachers over most other media is that they can act as an 'assistant looking over your shoulder' and give instructions when they are needed by the student to correctly perform the procedural aspects of the task.

\subsection{Component 4: Part-task practice}

Learning tasks appeal to the problem-solving, reasoning and decision making aspects, as well as the procedural aspects of a complex skill or competency. As a rule, they provide enough practice to learn both aspects. Additional part-task practice of procedural aspects is only needed when a very high level of automatism is needed and when the learning tasks do not provide the required amount of practice. Familiar examples are the multiplication tables of 1 to 10 in primary school (in addition to whole arithmetic tasks, such as paying in a shop or measuring the area of a floor), or giving intravenous injections in a nursing programme (in addition to whole tasks such as patient intake). Pedagogical methods provide repetitive practice with immediate, corrective feedback (Anderson, 1993). For students, it is important to start part-taskpractice after they have been confronted with the procedural aspect in the context of meaningful learning tasks. Only then will they understand how developing the routine may help them to improve their performance in whole tasks.

\section{I PHASE 2: SEATING ARRANGEMENTS AND PHYSICAL SPACES}

The first phase yields a common vision on how to reach the final attainment of an educational programme by giving a description of (a) the type of learning tasks that students will work on and how they will be guided, (b) the ways supportive and procedural information will be provided to students and how it will be discussed with them, and (c) the type of part-tasks for which students need repetitive practice. These pedagogical decisions have implications for the design of the physical environment. This section discusses the design process that adjusts seating arrangements and physical learning spaces to the chosen pedagogies. Here, we note key balancing considerations in the design of learning environments as described by Mäkelä and Helfenstein (2016), namely communality-individuality; comfort-health; and novelty-conventionality. We view the aspects of comfort (e.g. aesthetics, luminosity) and health (e.g. air quality) as crucial across all four components and less in need of balance per se. In contrast, the balance of communityindividuality needs particular mention in relation to learning tasks, as does the balance of novelty-conventionality with regard to its role in part-task practice.

\section{$3.1 \mid$ Learning tasks}

For each of the four educational components, participants in the design process think about the activities that learners will perform (learner activities), the size and organisation of the student groups that will perform these activities (seating 
TABLE 2 Examples of possible learner activities, seating arrangements and physical spaces for each of the four educational components

\begin{tabular}{|c|c|c|c|}
\hline & Learner activities & Seating arrangements & Physical spaces \\
\hline $\begin{array}{l}\text { Learning } \\
\text { tasks }\end{array}$ & $\begin{array}{l}\text { Project work, work on professional } \\
\text { tasks, work on tasks in simulated } \\
\text { setting, collaborating, reflection-in/ } \\
\text { on-action, performance-based } \\
\text { assessment etc. }\end{array}$ & $\begin{array}{l}\text { Small group work guided by teacher/ } \\
\text { tutor (groups between } 4 \text { and 12), } \\
\text { simulation-based team training, } \\
\text { simulation-based individual training } \\
\text { etc. }\end{array}$ & $\begin{array}{l}\text { Project room, } \\
\text { high-fidelity simulation } \\
\text { laboratory, workplace } \\
\text { etc. }\end{array}$ \\
\hline $\begin{array}{l}\text { Supportive } \\
\text { information }\end{array}$ & $\begin{array}{l}\text { Studying books, listening to lectures, } \\
\text { watching educational videos, ex- } \\
\text { ploring micro-worlds, using multi- } \\
\text { media and hypermedia, discussing } \\
\text { with peers, participating in a Socratic } \\
\text { dialogue, written examinations etc. }\end{array}$ & $\begin{array}{l}\text { Individual study, medium to large } \\
\text { groups (12-500), library, home } \\
\text { study, computer rooms etc. }\end{array}$ & $\begin{array}{l}\text { Lecture room, meeting } \\
\text { room, quiet individual } \\
\text { study places, computer } \\
\text { room etc. }\end{array}$ \\
\hline $\begin{array}{l}\text { Procedural } \\
\text { information }\end{array}$ & $\begin{array}{l}\text { Listen to instructor during practice, } \\
\text { consult mobile technologies, consult } \\
\text { manuals or quick reference guides } \\
\text { when needed, augmented reality etc. }\end{array}$ & $\begin{array}{l}\text { Same as for learning tasks and, if } \\
\text { applicable, part-task practice }\end{array}$ & $\begin{array}{l}\text { Same as for learning } \\
\text { tasks and, if applicable, } \\
\text { part-task practice }\end{array}$ \\
\hline $\begin{array}{l}\text { Part-task } \\
\text { practice }\end{array}$ & $\begin{array}{l}\text { Individual computer-based instruc- } \\
\text { tion, individual repetitive practice } \\
\text { with paper and pencil, technical skills } \\
\text { training, part-task training etc. }\end{array}$ & $\begin{array}{l}\text { Individual work places, (near) peer } \\
\text { tutoring, dedicated setups for prac- } \\
\text { ticing technical skills etc. }\end{array}$ & $\begin{array}{l}\text { Skills laboratory, com- } \\
\text { puter room, individual } \\
\text { work places etc. }\end{array}$ \\
\hline
\end{tabular}

arrangements), and the physical learning spaces in which these seating arrangements can be realised (physical spaces; see Table 2). This is an open-ended and creative process. Although the chosen pedagogies from the first phase will have implications for the design of the physical environment and pose constraints, the same pedagogies may still take place in a multitude of seating arrangements and physical learning spaces. Thus, non-pedagogical considerations dealing with available resources, personal preferences, cost- and time-effectiveness, and so on, also play an important role.

For the learning tasks, it should first be decided how these will be organised. Here, great variations are possible and it is critical to explore different design options. Figure 1 shows different options, and exploration of these can help

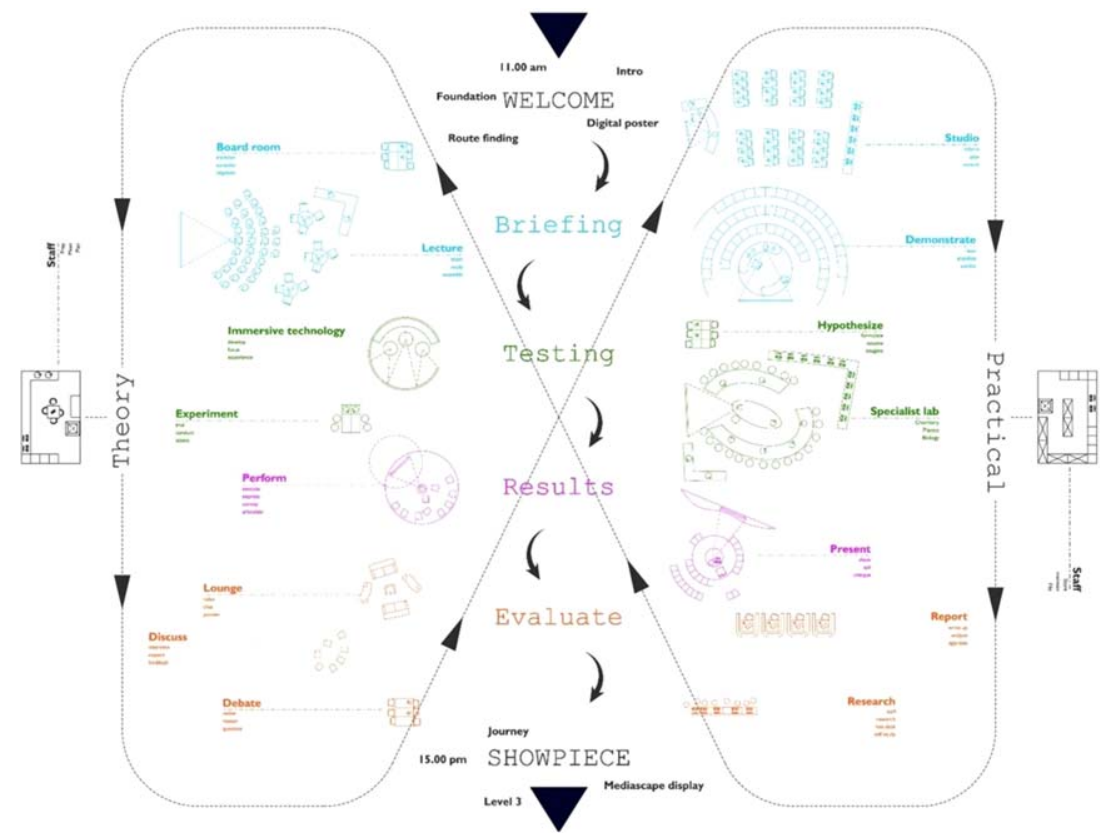

FIGURE 1 A visual representation coupling supportive information (theory - left part) and learning tasks (practical - right part) to learner activities and possible seating arrangements [Colour figure can be viewed at wileyonlinelibrary.com] 
to fine tune the underlying vision. Here, the community-individuality balance is particularly important. For example, following a problem-based approach, learners may work on 'problems' in medium-sized groups of 10 to 15 learners; following a project-based approach, learners may work on 'projects' in small groups of 4 to 8 students, or following a competence-based approach, learners may mainly work individually on 'professional tasks'. This will narrow down possible seating arrangements and, consequently, the design of physical learning spaces (see right part of Figure 1). For medium-sized groups working on problems, one option could be to seat students in groups of 12 in an open square with 3 students at each side (or use standing desks to keep students more actively involved), and to plan separate educational rooms for groups. For small-sized groups working on projects, one option could be to seat students in groups of 6 at hexagonal tables and plan separate project rooms, but another, more cost-effective option could be to have larger physical spaces in which a number of project groups can work at the same time. Finally, for individuals working on professional tasks, one option could be to organise a simulated workplace; for example, a hairdressing programme in vocational education could organise simulation facilities so that students can individually practise washing hair, cutting, curling, colouring and dry-blowing. Yet another option could be to set up a hairdressing salon that is associated with the school.

\subsection{Supportive and procedural information}

For supportive information, again variations are possible and need to be explored as part of the design process (see left part of Figure 1). For example, for students working according to a problem-based approach in groups of 12 in separate educational rooms, the study of supportive information (i.e. learning resources) that is necessary to solve the problems may be completely self-directed and students can search and study this supportive information in a school library with individual study places. Yet, other options could be to offer this information only online, so that it can be studied at home, in traditional lectures, which would require some kind of lecture rooms, or combinations of these. As another example, for students working on projects in groups of 6 in separate project rooms, the presentation of the information they need to perform the projects could require some kind of lecture room. But when the project groups work in one large physical space that can be flexibly used, the seating arrangements may be reorganised in such a way that supportive information can be provided by a teacher to all project groups simultaneously. Finally, for students who work individually on professional tasks, it is not uncommon that different students work on different tasks in order to make efficient use of available simulation facilities (e.g., some students practise washing hair, others curling or cutting hair, etc.). This makes the option of presenting the same supportive information to all students at the same time in one large lecture room less efficient. More viable options in this case could be to present and discuss supportive information online or to have students sign up for small-group presentations on particular topics.

For procedural information, the 'design space' is considerably smaller than for the learning tasks and supportive information. This is because it is presented to learners while they are working on the learning tasks (or, if applicable, while they are working on part-task practice - see below). Thus, when seating arrangements and physical learning spaces have been decided on for the learning tasks, the setting in which procedural information will be provided is also determined. Yet, there are still options to consider regarding the media that will be used for its presentation. For example, for problem-based learning groups working in separate educational rooms, a tutor can be made available for each group, or it could be 'tutorless' groups that are expected to consult their mobile devices when procedural information is needed. For smaller project groups working in one large physical space, it could be feasible to have an instructor who can provide procedural information to all groups when he or she is acting as an 'assistant looking over the shoulder', but for project groups working in separate project rooms, it could be more feasible to provide the groups with quick reference guides or mobile apps that can provide them with the necessary procedural information when needed. And for students working on individual professional tasks, it may be impossible for one teacher to provide procedural information to all these students. A better option could be to present 'how-to' instructions on posters on the wall of the simulation room or, in the near future, to use augmented reality where how-to instructions are presented through Google glasses when a student needs them (e.g., when a hairdressing student is looking at a particular hair colouring, just-in-time instructions are projected on how to safely use this particular product). 


\section{3 | Part task practice}

Finally, decisions need to be made with regard to part-task practice. Many relate to the balance of novel facilities versus conventional ones. For some educational programmes, part-task practice might not be needed at all, because routine skills can be sufficiently practised in the context of whole learning tasks. Yet, for problem-based learning programmes, so-called 'skills laboratories' are set up so that students can practise skills under the direct supervision of an instructor. And also for project groups, practicals, science labs and/or computer labs may give students the opportunity to practise routine skills. For other programmes based on professional tasks, simulation facilities that are available for the learning tasks could be used for part-task practice. For example, in a hairdressing programme with fullyequipped simulated hairdressing salons, the same simulation facilities (e.g., models with wigs) can be used for part-task practice.

\section{4 | PHASE 3: CONSTRUCTING THE SCHOOL BUILDING}

Typically, the involvement of school management, teachers and students is limited during the realisation of the actual school building. However, since some construction constraints only become visible during the realisation phase, it is common for designs to be updated on the fly.

In such cases, as Koutamanis, Heuer, and Könings (2017, pp. 295-305) note, 'as information custodians they still have to monitor changes as they appear in the model and keep track of how the design is implemented, so that they can react to any unwanted deviations from what was agreed in briefing or designing'. Examples of design refinements that are not uncommon at this stage include changes in wall coatings, floors, or placement of electrical sockets. Since each of these can have ramifications of teaching and learning, the input of school management and teachers is important. Additionally, for teachers and school management, this phase includes preparing for actual use of the building by moving plans or training with new facilities.

\subsection{Participatory design across the phases}

Our secondary schools are among the last Fordist institutions, where people in large numbers go, all at the same time, to work in the same place, to a centrally devised schedule announced by the sound of a bell (Tracy Kidder, 1989).

This quote, which dates back more than 25 years, may still be true for part of our schools. But more and more schools are moving into the $21^{\text {st }}$ century and becoming more responsive to current societal needs. In the UK, policy took a pioneering position with the Building Schools for the Future (BSF) programme, which aimed to redesign all English secondary schools. In this programme, the importance of consulting teachers, students and the wider community in a participatory design approach was stressed by the government. This interest in participatory approaches to the design of the physical learning environment is most obvious in the UK, but can also be found in other European countries. Participatory design across the three phases is discussed in the next section. Thereafter, two case examples are described, namely, the UCL Academy in London and De Werkplaats Kindergemeenschap in Bilthoven (The Netherlands).

Adjusting seating arrangements and physical learning spaces to a particular pedagogical design is an open-ended and creative process and is pre-eminently a phase in which educationalists and architects must cooperate. Yet, this is not to say that participatory design is not important in the earlier and later phases of the process. As described in the model presented by Könings, Bovill, and Woolner (2017, pp. 306-317), we envision an iterative design process until the moment when the school building has been realised, with different stakeholders being involved in each of the three phases of the design process. The dominant partners in the first phase, that is, the specification of the pedagogy, are school management, teachers and students; the dominant partners in the third phase, that is, the realisation of the school building, are architects, interior designers, educational publishers and ICT specialists. But especially in the 
second phase, where seating arrangements and physical learning spaces are adjusted to the chosen pedagogy, it is critical that all partners contribute in an equal relationship.

In the first phase, the pedagogy is specified for how students will work on their learning tasks and be guided in this process, how they will be presented with supportive and procedural information, and how they will practise parttasks or routines. In addition, for each of these educational components, decisions need to be made on how assessments will be organised. Most research on participatory educational design has been concerned with this first phase. For example, there is growing evidence of the importance of: (a) including representatives from the labour market and/ or young professionals in order to ensure that education is preparing for the future labour market (Woolner \& Clark, 2015), (b) empowerment of teachers in the design process in order to increase the quality of teaching (Cober, Tan, Slotta, So, \& Könings, 2015), (c) including students in the design process in order to increase their satisfaction with the learning process (Könings, Brand-Gruwel, \& van Merriënboer, 2010), and (d) taking the perspectives of both teachers and students into account in order to prevent unproductive discrepancies in their perceptions and expectations (Könings, et al. 2014). Thus, in this first phase, school management and instructional designers must work closely with future employers, teachers, students, and possibly parents in order to have a clear picture of final attainment levels and how learning and assessments will be organised to reach those levels. Architects, interior designers, ICT specialists and educational publishers may participate in this process, but their role is mainly that of listeners who provide a sounding board for the generated ideas.

In the second phase, where seating arrangements and physical spaces are adjusted to the chosen pedagogy, participatory design between educators and students on the one hand, and architects, interior designers, ICT specialists and educational publishers on the other, is critical. The number of participants will be largest in this phase. This also affects the chances that the opinions and needs of differing groups of participants may be in conflict with each other (Burke $\&$ Könings, 2016), thus increasing the complexity of the process and jeopardising the quality of its results. Suggestions on how to steer this process include the use of facilitators to ease communication between groups (Woolner, McCarter, Wall, \& Higgins, 2012), the use of divergent thinking techniques to promote creativity (Bland, 2015), and the use of visualisation techniques to stimulate the exchange of ideas (Clark, 2010; Koutamanis et al., 2017, pp. 295-305). In the study by Könings et al. (2017, pp. 306-317), participants also mentioned field trips and visits to places applying different approaches as valuable ways to reach a common vision.

In the third and final phase when the school building is realised, the dominant stakeholders will be architects, interior designers, educational publishers and ICT specialists. The role of teachers and students shifts from that of designers to future users. A range of possibilities needs to be created and carefully evaluated: Imagining physical spaces is very difficult, and full scale models are extremely valuable in this final phase of the process. Students and teachers can experiment with different mock-ups of classroom furniture, physical spaces, technological tools, and even the placing of walls and roofs. This experimental phase continues in an iterative fashion until the final design becomes more concrete. But even this final design must allow for future flexibility - education always requires adaptation, and schools must be designed for change so that they allow educational goals to be implemented in a variety of settings. Moreover, schools are linked to the community and society, and their envisioned role in how they form part of the wider physical environment should be expressed. So, schools can and should be invented anew by each generation of teachers and students.

Based on the phase-specific descriptions given previously and the participatory design considerations mentioned in this section, Table 3 presents an overview of key elements in the three-phase participatory design of pedagogy and learning spaces. Thereafter, these ideas are illustrated by two case examples presented in the next section.

\section{5 | CASE EXAMPLES}

\subsection{UCL Academy, London}

The UCL Academy is a secondary school located in London and sponsored by University College London (UCL). The design process took place in the context of the Building Schools for the Future programme and SCABAL architects served as client design adviser. The school opened in 2012 and its pedagogy can be described as an interplay between 
TABLE 3 Key elements in three-phase participatory design of pedagogy and learning spaces

\begin{tabular}{|c|c|c|}
\hline & Key processes & Participatory notes \\
\hline $\begin{array}{l}\text { 1: Specifying the } \\
\text { pedagogy }\end{array}$ & $\begin{array}{l}\text { Design learning tasks } \\
\text { Identify supportive information } \\
\text { Identify procedural information } \\
\text { Create part-task practice scenarios }\end{array}$ & $\begin{array}{l}\text { School management and instructional de- } \\
\text { signers work with school leaders, teachers, } \\
\text { students and possibly parents }\end{array}$ \\
\hline $\begin{array}{l}\text { 2: Seating arrangements } \\
\text { and physical spaces }\end{array}$ & $\begin{array}{l}\text { Envision enactment of the pedagogy } \\
\text { Derive space requirements } \\
\text { Attend to: } \\
\text { - comfort } \\
\text { - health } \\
\text { - communality-individuality balance } \\
\text { - novelty-conventionality balance }\end{array}$ & $\begin{array}{l}\text { Educators and students work with architects, } \\
\text { interior designers, ICT specialists and edu- } \\
\text { cational publishers }\end{array}$ \\
\hline $\begin{array}{l}\text { 3: Realising the } \\
\text { school building }\end{array}$ & Monitor detail decisions or changes & $\begin{array}{l}\text { architects, interior designers, educational } \\
\text { publishers and ICT specialists collaborate, } \\
\text { educators and students monitor }\end{array}$ \\
\hline
\end{tabular}

the four components outlined as part of phase 1. Its architectural design provides an excellent illustration of how pedagogy can be aligned with seating arrangements and physical learning spaces, as described in phase 2 . The curriculum of UCL Academy focuses on real-world issues (called 'big ideas'), problem-solving, and the development of complex skills. Learning tasks include extensive project work, participation in community activities, internships, and international exchanges. The UCL Academy operates on 'stage-not-age' principles, with students moving through the curriculum levels as they are ready (see levels of complexity described in phase 1), and not necessarily when they reach a particular age. In addition, they can make personal choices in building a curriculum that meets their needs and aspirations.

The school has a very strong focus on community and belonging. All students and academic staff are members of one of the five Households. The Households each have a House space which provides places for students and academic staff to eat together, relax, and study before and after school. Every space belongs to a Household whose members are responsible for 'hosting' these facilities for the rest of the Academy community. Students belong to the same Household for the duration of their studies at the Academy, enabling them to build a strong Household identity and be provided with academic support and guidance from those who know them best: their tutors, their fellow students and the head of their Household. Inter-Household competitions form an important element of life at the UCL Academy, with students competing to score the highest in particular academic subjects, service to the community and sports events.

Each of the five Households has a Superstudio, which is a group of linked learning and teaching spaces which encourages students to move between activities and work collaboratively and across disciplines. Central to this group is a large flexible Open Learning space that allows students to work on cross-curricular and multidisciplinary learning tasks, that is, real-world problems and projects that tackle 'big ideas'. Thus, a highly flexible use of furniture and other facilities makes it possible to easily align chosen pedagogies with physical learning spaces. Students spend as much as $60 \%$ of their learning time working in Superstudios, so comfort and health were important design issues. Special attention had to be paid to acoustics in the relatively large open spaces. Collaborative learning is strongly promoted and students typically work on learning tasks in sets of six, seated at standard hexagonal tables (see Figure 2a). A Superstudio can be flexibly used by a number of different size groups simultaneously, including as a traditional classroom (see Figure $2 \mathrm{~b}$ ), as a small or large seminar room (using multitudes of the 'learning set of six'), or as an open physical learning space which can accommodate a range of teacher- and student-led activities at any one time.

The learning environment offered by UCL Academy is unfamiliar to most of its new students, both in terms of the learning tasks that stress collaboration and multidisciplinary real-world projects, and of the Superstudio as a dynamic physical space to work on these projects and problems. Therefore, in their first year, students are guided in their adaptation to the new learning environment and in planning their own programme of study in the years ahead. Hence, they develop a wide variety of $21^{\text {st }}$ century skills that are essential for effective learning. After they complete the first year, they choose their courses. For basic courses, they participate in a 'set of six' that is their home group, for elective courses, they participate in a 'set of six' that is an 'away group'. Students move through three course levels. Most are 

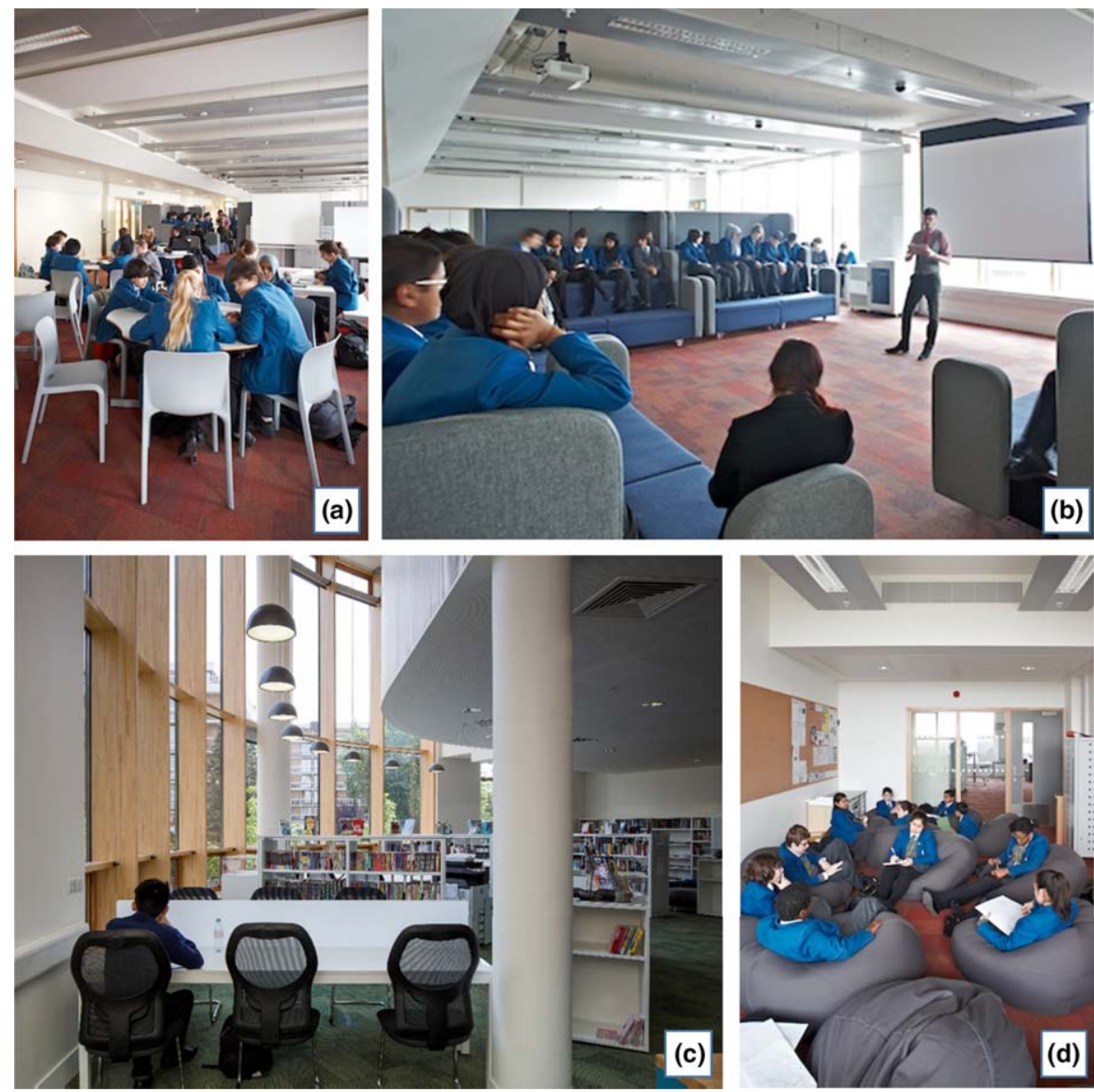

FIGURE 2 Seating arrangements and physical learning spaces at UCL Academy [Colour figure can be viewed at wileyonlinelibrary.com]

likely to be enrolled in Level 1 and Level 2 courses from 14 to 16 and Level 2 and Level 3 courses from 15 to 18 . All students are expected to follow English, mathematics and science courses at Level 2 before age 16. But, within these constraints, there is great flexibility in planning individual learning trajectories.

Whilst the Superstudios are at the heart of the teaching and learning processes at UCL Academy, they also offer a range of other physical learning spaces. Supportive information, for example, is not only presented by a teacher in the Superstudio, but may also require self-study using electronic devices (see Figure 2c) and written materials (see Figure 2d). These spaces for individual study are available throughout the building. In addition, a diversity of skills (e.g. parttask practice) can be practised in science and engineering laboratories. There is also a science theatre for demonstration, experiments, and talks by visiting academics from UCL. And there are performance spaces where students can present their academic work, but also perform art, music and drama. In order to make optimal use of the available space, there are only outside corridors connecting different parts of the building. An auditorium that is large enough to seat all students and academic staff of the school is also located outside. Table 4 presents an overview of key elements in the three-phase participatory design of pedagogy and learning spaces as they played out in the ULC case.

\section{2 | De Werkplaats Kindergemeenschap, Bilthoven}

De Werkplaats Kindergemeenschap (Children's Workshop Community) includes a kindergarten, a primary school and a secondary school in Bilthoven, The Netherlands. It was founded by Kees Boeke (1884-1966), who resisted the dominant idea that school was a place of rigid discipline and information transmission. In 1926, the school started in one room in a friend's house, and after steadily growing, it now has about 1800 students. In Boeke's radical vision, children 
TABLE 4 Key elements in the UCL Academy example

$\begin{array}{ll}\text { 1: Specifying } & \text { Pey processes } \\ \text { the pedagogy } & \text { (BSF) program; visits to several schools in } \\ \text { UK, Denmark (Hellerup and Orsestad) and } \\ \text { the Netherlands (de Werkplaats); study } \\ \text { exemplary classroom design projects con- } \\ \text { ducted by SCABAL and other architects; } \\ \text { input from retired teacher sympathetic to } \\ \text { pedagogical model used. }\end{array}$

2: Seating arrangements and physical spaces

Eye for comfort with emphasis on furniture, thresholds, belonging and circulation; focus on health is strict requirement of the BSF program - acoustics required special attention; community and community building is at the heart of the approach (cf. Households); novelty outbalances conventionality.

\section{3: Realising the} school building

As client design advisor, SCABAL choose the consortium to build the building; role

\section{Participatory notes}

Frequent drawing/briefing workshops with UCL representatives; drawing workshops with students at UCL's architecture school; focus groups with formers from comprehensive schools; briefings with co-located Swiss Cottage Special school; meetings with BSF management team; input from ICT and management advisors.

Ongoing conversation between all stakeholders involved; yet limitations to achieving desired balance due to complex/lengthy procurement process and stop-start problems created by changes of government; realised design is meant to enable ongoing participation and engagement. went up to handover and beyond; continue to visit and monitor but formal engagement slowly disappears; "we made it, they use it".
Still good working relations between all stakeholders involved in the design and building process; BSF partners (SCABAL and Cambridge University) have collaborative PhD students who work with UCL academy.

had to learn in an atmosphere of freedom and responsibility. This vision stressed relative freedom when it came to what to learn and how to learn it and taking responsibility for both personal well-being and the well-being of the school and the broader community. The guiding pedagogical principles were that knowledge was constructed in a social process, that discipline was the result of taking responsibility, and that cooperation between students and between students and teachers drove learning (Burke \& Könings, 2016).

The original building was designed by Frans Röntgen and opened in 1929 (see Figure 3a). For the time, it was a modern, quarter circle building with a flat roof containing five classrooms connected by a curved corridor which housed the library. In 1934, an extra wing was added with an auditorium and rooms for arts and gymnastics. Although there were classrooms, children were not divided by age - children of different ages shared the same classroom. In order to stress the feeling of community, glass was used in all walls to emphasise connectedness; as students could see each other and their teachers. Besides traditional school subjects, students had to fulfil house-keeping tasks, had daily exercise, and took lessons in the garden which was designed in harmony with the school building. The leading pedagogy was illustrated by the weekly assemblies, which were led by one of the students and where decisions were made on the division of tasks and disciplinary actions. Teachers and students participated in these assemblies and decisions were only taken when everyone agreed.

From 1951 onwards, new, more traditional buildings were erected because of the growth of the school. The original building closed in 1974. For several decades, De Werkplaats Kindergemeenschap no longer profiled itself as a radical reform school, it simply became a 'good and popular' school with some special characteristics. However, in the early 2000 s, the school management started to develop plans for a new building for the secondary school, with the strong ambition to express the guiding pedagogical principles of Kees Boeke in the new architecture. Although the new school had to meet all modern demands, it was argued that the guiding pedagogical principles of Kees Boeke were of particular importance for the $21^{\text {st }}$ century and should be reflected in the interior and exterior design. Thus, the design of the new school building was seen as a special opportunity to refresh the pedagogical principles of Kees Boeke, and his daughters provided input to do so. Then, in cooperation with M3V, a consultancy firm specialised in the development of public real estate, a 'designing down process' was started in which school management, students, teachers, parents, architects and others collaborated in developing a new vision of teaching and learning that had to be expressed in the new building design. This was done in an integrative and participatory design approach, including the three phases discussed in this article.

In the newly-developed vision, students primarily work together on learning tasks in the traditional sense and on learning tasks that are meaningful for their community and/or society at large. They are partly self-directed and take 

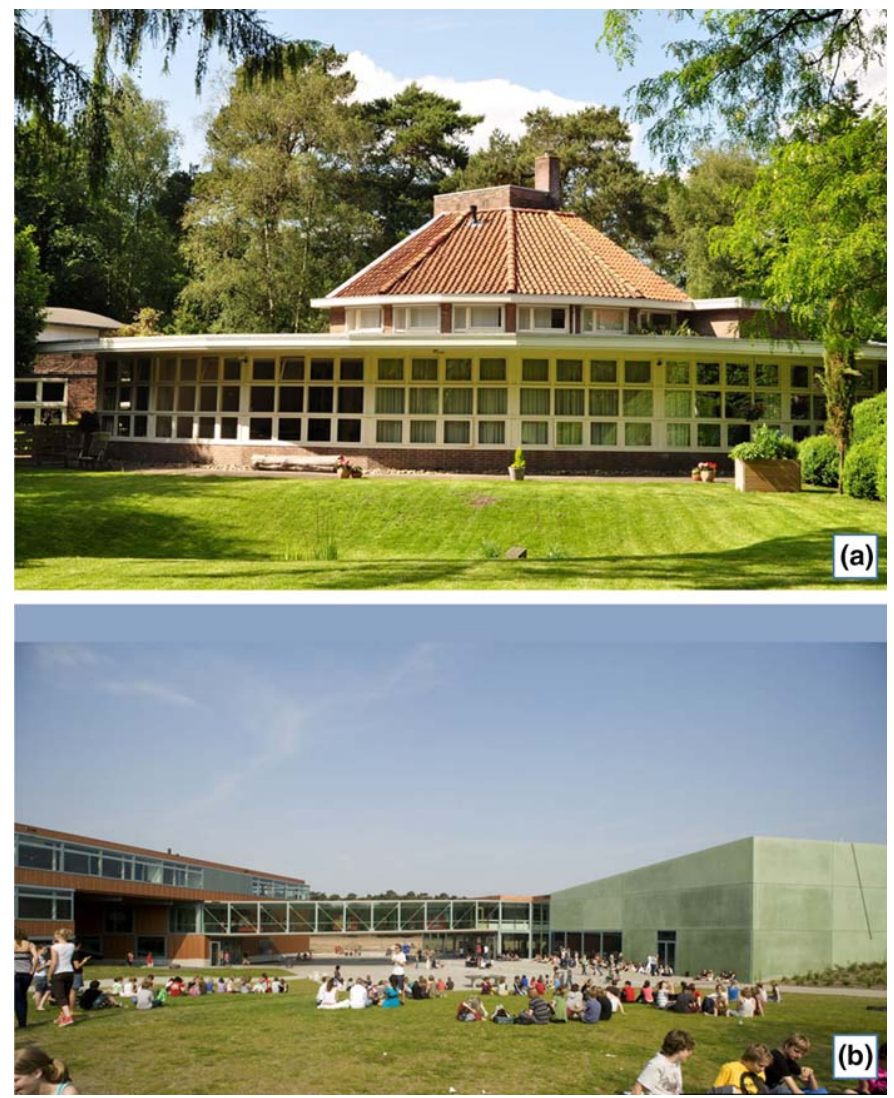

FIGURE 3 De Werkplaats Kindergemeenschap: Original building (a) and new building (b) [Colour figure can be viewed at wileyonlinelibrary.com]

responsibility for their own learning and the learning of their peers. In the new school building, this is clearly reflected in the central role given to large open spaces or 'learning domains'. In these domains, there is space for 75 to 80 'workers' (students) and their teachers. Two domains together are the base for a team of teachers and students. The learning domains resemble the Superstudios of UCL Academy, that is, they offer a large space where teams of students work on different learning tasks and can be guided by teachers. The new physical learning spaces and the way of working have had an enormous impact on teacher cognition and behaviour. As professionals, teachers are together responsible for the educational programme and the pedagogical atmosphere in their team.

With the new building, the secondary school of De Werkplaats Kindergemeenschap became once again more of a 'workshop', as implied by its name and in line with Boeke's ideal of children as collective workers engaged in practical activities aimed at constructing knowledge and building their community. It is interesting to note that, as part of the 'designing down process', pilots with 'improvised' learning domains were set up in the old school building. This gave students and teachers the opportunity to experiment with learning and teaching in the new physical spaces and come up with suggestions for the new building. This also helped school management, students and teachers to inspire confidence ('we can do it!'), even before moving to the new school building.

In addition to the open learning space, every domain in the new school building (see Figure $3 b$ ) has a presentation room for 25 to 30 students to listen to lectures and presentations and a small room for groups of 8 to 10 students. There are also special rooms for arts and crafts and laboratories for skills training, a library, a theatre (also used for presentations, etc.) and a restaurant. Thus, student teams working on tasks in the open learning domains form the heart of the learning community, but there are also physical spaces designed to support this work. Key elements of the three-phase participatory design process for the De Werkplaats case are summarised in Table 5. 
TABLE 5 Key elements in the De Werkplaats example

\begin{tabular}{|c|c|c|}
\hline & Key processes & Participatory notes \\
\hline $\begin{array}{l}\text { 1: Specifying } \\
\text { the pedagogy }\end{array}$ & $\begin{array}{l}\text { Input from daughters of Kees Boeke, } \\
\text { educational advisors and researchers. } \\
\text { Two-year 'designing-down' process led } \\
\text { by M3V; visit to school who worked with } \\
\text { M3V before; visits to schools already } \\
\text { working with open learning spaces (with } \\
\text { school management, teachers and par- } \\
\text { ents);; experimenting with the new } \\
\text { pedagogy in several pilots organized by } \\
\text { teacher teams in the old school building. }\end{array}$ & $\begin{array}{l}\text { Preliminary workshops with teachers; } \\
\text { brainstorm sessions, first with school } \\
\text { management, later with increasingly lar- } \\
\text { ger groups of teachers on locations away } \\
\text { from the school; input from; workshops } \\
\text { with parents; limited participation of } \\
\text { students (with hindsight, students could } \\
\text { have been more involved in this phase); } \\
\text { experimenting with the new pedagogy in } \\
\text { several pilots organized by teacher teams } \\
\text { in the old school building. }\end{array}$ \\
\hline $\begin{array}{l}\text { 2: Seating arrangements } \\
\text { and physical spaces }\end{array}$ & $\begin{array}{l}\text { Triple 'activities-educational methods- } \\
\text { group size' is used to make decisions on } \\
\text { different types of learning spaces; open } \\
\text { learning spaces pose special require- } \\
\text { ments to climate and acoustics; interior } \\
\text { designer works closely together with } \\
\text { teachers and students; ICT specialists } \\
\text { work relatively independently (did not } \\
\text { take part in the working groups, but } \\
\text { advised directly the business director } \\
\text { who led the building process). }\end{array}$ & $\begin{array}{l}\text { Diverse working groups (for domains, } \\
\text { STEM, creative subjects, library, restau- } \\
\text { rant etc.) prepare programs of require- } \\
\text { ments; feedback on programs of } \\
\text { requirements from building team; work- } \\
\text { ing groups visit other schools; regular } \\
\text { meetings with parents; specialists (ICT, } \\
\text { interior design) were hired to realize } \\
\text { programs of requirements. }\end{array}$ \\
\hline
\end{tabular}

3: Realising the school building
During realisation: communication between the different working groups who had been involved in establishing the PvE.

After realisation of the building: Teacher teams play central role; weekly teacher-team meetings; sometimes, special advice is sought to find out how to make best use of affordances of the new environment (e.g. domain management, team work, ICT facilities).
All AECO-specialists were represented in the 'building team'; the overall project leader organized weekly meetings of the building team; school management and ICT project leader were usually present in the weekly meetings.

\section{6 | DISCUSSION}

We began this article from the viewpoint that the quality of education suffered when pedagogies were not fully aligned with physical learning spaces. This problem is found with old school buildings that do not fit modern pedagogies, but also with brand new school buildings that have been designed without giving a central role to a pedagogical vision that is shared by its users. Thus, there is a clear need for an integrative design approach that helps to reach an optimal alignment of pedagogies and the physical environment. We distinguished three phases in such a design process: the specification of a pedagogy, which can be described as an interplay of four basic educational components; the alignment of the chosen pedagogy with seating arrangements and physical learning spaces; and the realisation of the school building. Although we described the three phases as a linear sequence, they are better seen as a cyclical process in order to reach the best (eventual) match between buildings and pedagogies. The model does not advocate a particular fixed process, but does draw attention to key considerations over time and thus provides an important lens to examine specific cases.

The three-phase model gives rise to a number of important observations. First, participatory design is important in all three phases, but especially difficult to realise in the second phase because that is where educators, teachers and students on the one hand, and architects, interior designers, ICT specialist and educational publishers on the other must align pedagogies with seating arrangements and physical learning spaces (see also Koutamanis et al., 2017, pp. 295-305). It is during this phase that pedagogical and non-pedagogical considerations (resources, preferences, costeffectiveness etc.) will often clash and in which the largest number of stakeholders is involved. Future research is needed into effective methods to guide this process. 
Second, we stressed that the successful implementation of educational innovations did not only depend on the instructional design (i.e., phase 1), but also on the arrangement of the physical environment in which instruction and learning take place. Participatory design may help to design seating arrangements and physical spaces and to realise a school building that supports teaching and learning because use is made of the expertise, experiences and input of all relevant stakeholders. Yet, we need more research on how seating arrangements and physical spaces affect learning (Tondeur, de Bruyne, van den Driessche, McKenney, \& Zandvliet, 2015) so that the later phases in the design process can also be based on scientifically-grounded findings.

Third, whilst the physical environment may directly influence student learning in subtle ways, it seems to play an even more powerful role in facilitating or inhibiting teachers as they structure learning opportunities for their students. This was visible in the Werkplaats Kindergemeenschap example where teachers' cognitions and behaviours changed as a result of the introduction of the learning domains - they stressed the importance of working in teacher teams. Thus, future research should not limit itself to studying the effects of noise, temperature, lightning, colour of the walls, or height of the ceiling on student learning (for an overview, see Choi, van Merriënboer, \& Paas, 2014), but also on how the seating arrangements and other characteristics of physical learning spaces affect teacher cognition and behaviour. For example, Brooks (2016) compared the effects of a traditional classroom and a technology-enhanced active learning classroom on teacher behaviour and found that different classroom types were causally linked to great observed differences in this behaviour.

Before concluding, we will pause to reflect on the fact that this article offers recommendations for the participatory design of new buildings, not existing schools. Whilst it seems plausible that the participatory approach described here could be adapted to the interior re-design of classrooms, it seems that the changes would be major and that further research would be necessary to render it suitable for that purpose, given the challenges of legacy environments. Perhaps the problems here are not so different from those concerning innovation in education: designing new programmes is much easier than re-designing existing ones. This seems like a worthwhile endeavour, not only because there are more existing schools than new ones, but also because, in time, the newness wears off, pedagogies evolve, and buildings become inhabited by different cohorts of teachers and learners. Furthermore, since most quality assurance systems suggest a major curriculum evaluation/revision every 5 to 6 years, re-assessing the fit between pedagogy and physical spaces should be an integral part of that evaluation. In existing schools, this process can be fed by information on student outcomes and attitudes in relation to the psychosocial learning environment, for example by using newly-developed instruments for the Place-Based Learning and Constructivist Environment Survey (PLACES) (Zandvliet, 2012).

Let us conclude with implications for educational policy. The main message is that the worst thing to do when planning a new school building is to conceive it as a 'building project'. It is of utmost important to launch a discussion with teachers and students on the pedagogies they see as important for reaching the final attainment levels of their educational programme. It is only in the development of a shared pedagogical vision that school management, teachers, students and parents on the one hand, and architects, interior designers, ICT specialists and educational publishers on the other should be brought together. Designing schools that successfully bring pedagogy and physical learning environment together is a very difficult, open and creative process. But, as shown by our examples of the UCL Academy and De Werkplaats Kindergemeenschap, this participatory design process can yield very rewarding outcomes when carefully planned and executed.

\section{REFERENCES}

Anderson, J. R. (1993). Problem solving and learning. American Psychologist, 48, 35-44.

Bland, D. (2015). Children's imaginations at the centre of design for education. In P. Woolner (Ed.), School design together (pp. 153-166). Abingdon, UK: Routledge.

Brooks, D. C. (2016). Space and consequences: The impact of different formal learning spaces on instructor and student behaviour. Journal of Learning Spaces, 1. Retrieved from http://libjournal.uncg.edu/jls/article/view/285/275

Bruner, J. (1960). The process of education. Cambridge, MA: Harvard University Press.

Burke, C., \& Könings, K. D. (2016). Recovering lost histories of educational design: A case study in contemporary participatory strategies. Oxford Review of Education, 24(6), 721-732. 
Choi, H. H., van Merriënboer, J. J. G., \& Paas, F. (2014). Effects of the physical environment on cognitive load and learning: Towards a new model of cognitive load. Educational Psychology Review, 26, 225-244.

Clark, A. (2010). Transforming children's spaces: Children's and adults' participation in designing learning environments. Abingdon, UK: Routledge.

Cober, R., Tan, E., Slotta, J. D., So, H. J., \& Könings, K. D. (2015). Teachers as participatory designers: Two case studies with technology-enhanced learning environments. Instructional Science, 43, 203-228.

Fisher, K. (2005). Research into identifying effective learning environments. Evaluating Quality in Educational Facilities, 9 , 159-167. Retrieved from www.oecd.org/edu/innovation-education/37905387.pdf

Francom, G. M. (2017). Principles for task-centered instruction. In C. M. Reigeluth, B. J. Beatty, \& R. D. Myers (Eds.), Instructional design theories and models - The learner-centered paradigm of education (Vol. IV, pp. 65-91). New York: Routledge.

Kidder, T. (1989). Among schoolchildren. New York: HarperCollins.

Könings, K. D., Bovill, C., \& Woolner, P. (2017). Towards an interdisciplinary model of practice for participatory building design in education. European Journal of Education, 52, 306-317.

Könings, K. D., Brand-Gruwel, S. A. B., \& van Merriënboer, J. J. G. (2010). An approach to participatory instructional design in secondary education: An exploratory study. Educational Research, 52, 45-59.

Könings, K. D., Seidel, T., \& van Merriënboer, J. J. G. (2014). Participatory design of learning environments: Integrating perspectives of students, teachers, and designers. Instructional Science, 42, 1-9.

Koutamanis, A., Heuer, J., \& Könings, K. D. (2017). A visual information tool for user participation during the lifecycle of school building design: BIM. European Journal of Education, 52, 295-305.

Lodge, C., \& Reed, J. (2003). Transforming school improvement now and for the future. Journal of Educational Change, 4, 45-62.

Mäkelä, T., \& Helfenstein, S. (2016). Developing a conceptual framework for participatory design of psychosocial and physical learning environments. Learning Environments Research, 19, 411-440.

Marton, F., \& Pang, M. F. (2006). On some necessary conditions of learning. Journal of the Learning Sciences, 15, $193-220$.

Merrill, M. D. (2012). First principles of instruction. San Francisco, CA: Pfeiffer.

Muijs, D. (2010). Changing classroom learning. In A. Hargreaves, A. Lieberman, M. Fullan, \& D. Hopkins (Eds.), Second international handbook of educational change (pp. 857-866). New York: Springer.

Parlementaire Monitor. (2016). Verslag van een algemeen overleg, gehouden op 16 december 2015, over ROC Leiden. Retrieved from https://www.parlementairemonitor.nl/9353000/1/j9vvij5epmj1ey0/vk0vf11w7nzo

Renkl, A., \& Atkinson, R. K. (2003). Structuring the transition from example study to problem solving in cognitive skill acquisition: A cognitive load perspective. Educational Psychologist, 38, 15-22.

Tondeur, J., de Bruyne, E., van den Driessche, M., McKenney, S., \& Zandvliet, D. (2015). The physical placement of classroom technology and its influences on educational practices. Cambridge Journal of Education, 45, 537-556.

Van Merriënboer, J. J. G. (1997). Training complex cognitive skills. Englewood Cliffs, NJ: Educational Technology Publications.

Van Merriënboer, J. J. G. (2013). Perspectives on problem solving and instruction. Computers and Education, 64, 153-160.

Van Merriënboer, J. J. G., \& Kester, L. (2008). Whole-task models in education. In J. M. Spector, M. D. Merrill, J. J. G. van Merriënboer, \& M. P. Driscoll (Eds.), Handbook of research on educational communications and technology (3rd ed., pp. 441-456). Mahwah, NJ: Erlbaum/Routledge.

Van Merriënboer, J. J. G., \& Kirschner, P. A. (2013). Ten steps to complex learning (2nd rev. ed.). New York: Routledge.

Watson, L. (2007). Building the future of learning. European Journal of Education, 42, 255-263.

Woolner, P., \& Clark, A. (2015). Developing shared understandings of learning environments: Interactions with students, teachers and other professionals. In P. Woolner (Ed.), School design together (pp. 167-183). Abingdon, UK: Routledge.

Woolner, P., McCarter, S., Wall, K., \& Higgins, S. (2012). Changed learning through changed space: When can a participatory approach to the learning environment challenge preconceptions and alter practice?. Improving Schools, 15, 45-60.

Zandvliet, D. B. (2012). Development and validation of the place-based learning and constructivist environment survey (PLACES). Learning Environments Research, 15, 125-140.

How to cite this article: van Merriënboer JJG, McKenney S, Cullinan D, Heuer J. Aligning pedagogy with physical learning spaces. Eur J Educ. 2017;52:253-267. https://doi.org/10.1111/ejed.12225 